\title{
Chemical constituents and evaluation of cytotoxic and antifungal activity of Lantana camara essential oils
}

\author{
Lídia B. P. Medeiros, ${ }^{1}$ Márcio dos S. Rocha, ${ }^{2}$ Sidney G. de Lima, ${ }^{*}, 1,2$ \\ Gustavo R. de Sousa Júnior, ${ }^{1}$ Antônia M. das G. L. Citó, ${ }^{1}$ Davi da \\ Silva, ${ }^{1}$ José A. D. Lopes, ${ }^{1}$ Dinara J. Moura, ${ }^{3}$ Jenifer Saffi, ${ }^{3}$ Mitra \\ Mobin, ${ }^{4}$ José G.M. da Costa ${ }^{5}$
}

\begin{abstract}
${ }^{1}$ Departamento de Química, Universidade Federal do Piauí, Brazil, ${ }^{2}$ Centro de Tecnologia Farmacêutica, Universidade Federal do Piauí, Brazil, ${ }^{3}$ Departamento de Biofísica, Universidade Federal Rio Grande, Brazil, ${ }^{4}$ Faculdade de Ciências Humanas, Saúde e Tecnologias do Piauí, Novafapi, Brazil, ${ }^{5}$ Programa de Pós-graduação em Bioprospecção Molecular, Universidade Regional do Cariri, Brazil.
\end{abstract}

\begin{abstract}
The essential oil (EO) of aerial parts of Lantana camara L., Verbenaceae, from Simões, Piaui, Northeast of Brazil, were obtained by hydrodistillation and analyzed by GC-FID and GC-MS techniques. In total, 68 compounds were identified. The most representative compounds of the oil were mono and sesquiterpenes. The main compounds found in the oil of the leaves in different months were $\beta$-caryophyllene (10.5\%, in June of 2009), sabinene (7.98\%, in September of 2008), limonene (7.68\%, in September of 2008), spathulenol (11.64\%, in September of 2008). The oil from stems of L. camara was characterized by a largest amount of sesquiterpenoids, with spatulenol (15.9\%) and caryophyllene oxide (17.1\% in June of 2009), as main components. $\beta$-Gurjunene (32.7\%, in September of 2008) was the most prominent compound in the stems ' oils, which was absent or at very low relative abundance in leaves. L. camara essential oils from leaves were cytotoxic to V79 mammalian cells and also to Artemia salina, showing 50\% lethal concentration (LC50) values from $0.23 \mu \mathrm{g} / \mathrm{mL}$. The in vitro data obtained in this study suggested that EO may also be effective treating yeast infection in patients infected with fluconazole and terbinafine resistant isolates, but its toxicity must be monitored carefully.
\end{abstract}

Revista Brasileira de Farmacognosia Brazilian Journal of Pharmacognosy 22(6): 1259-1267, Nov./Dec. 2012

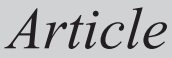

Received 8 Mar 2012

Accepted 25 Jun 2012

Available online 23 Aug 2012

Keywords:

Lantana camara essential oil chemical composition antifungal citotoxic activity

ISSN 0102-695X http://dx.doi.org/10.1590/S0102$695 \times 2012005000098$

\section{Introduction}

The genus Lantana, Verbenaceae, comprises about 150 species. Species of the genus Lantana have been used in several applications in folk medicine due to its antirheumatic, carminative, antiseptic, antispasmodic, emetic, antifungal and antitumoral activities. Lantana sp. is also used against bronchopulmonary diseases (Ghisalberti, 2000; Lorenzi \& Matos, 2002).

Many studies have reported that the genus Lantana displayed a variety of biological activities relating these activities to its chemical composition (Sousa et al., 2011; Sousa et al.,2010; Sousa et al., 2012; Costa et al., 2009; Costa et al., 2010; Sousa et al., 2009). Analysis of leaves stems and roots fixed extracts of genus Lantana indicated the presence of acid glycosides, alkaloids, flavonoids and triterpenes (Rwangabo et al., 1988; Herbert et al., 1991; Singh et al., 1991; Begum et al., 1995; O’Neill et al., 1998;
Weir et al., 1998; Begum et al., 2000; Mello et al., 2005; Litaudon et al., 2009). These secondary metabolites show several biological activities: antibacterial (Costa et al., 2009; Jiménez-Arellanes et al., 2007; Pereira et al., 2008), fungicides (Rwangabo et al., 1988; Sousa et al., 2009), inflammatory (Julião et al., 2009), anti-nematodes (Begum et al., 2000), inhibitors of $\alpha$-human thrombin (O'Neill et al., 1998; Weir et al., 1998), inhibitors of protein kinase C (Herbert et al., 1991) and inhibitors of protein Bcl-xL, a anti-apoptotic protein, of the family of Bcl-X (Hayashi et al., 2004; Litaudon et al., 2009).

In relation to chemical volatile constituents from genus Lantana, previously published studies showed a predominance of mono and sesquiterpenes (Sousa et al., 2010; Ngassoum et al., 1999; Silva et al., 1999; Misra \& Laatsch, 2000; Alitonou et al., 2004; Hernández et al., 2005; Sonibare \& Effiong, 2008). In this sense, we recently analyzed leaves of Lantana species by GC-MS 
collected in Ceará, Brazil, and it showed that essential oils from these species have in its composition mainly sesquiterpenes and sesquiterpenoids (Costa et al., 2009; Sousa et al., 2009). In general, Lantana sp. has larvicidal potential (Costa et al., 2010) and considerable antibacterial activity, including antibacterial activity against Sthaphylococcus aureus (Sousa et al., 2010). Results of L. camara, for example, showed an effect against Proteus vulgaris and Escherichia coli. Notably, for this oil the evaluation of toxicity LC50 revealed results with minor values to limit pattern of $1000 \mu \mathrm{g} /$ $\mathrm{mL}$ for Artemia salina. Moreover, the essential oil of L. achyranthifolia and L. camara showed antibacterial and antifungal activity against microorganisms that are actively working in respiratory and intestinal infections (Alitonou et al., 2004; Hernández et al., 2005; Sonibare \& Effiong, 2008). Several species are considered toxic, but the most important toxic species is L. camara, to cause photosensitization in ruminants when they ingest large quantities of leaves (Bastianetto et al., 2005).

As can be seen in the literature, the presence of interesting compounds in species of the genus Lantana and their potential activity have motivated our phytochemical study with L. camara specie widely distributed in Simões, Piauí, Brazil. In this sense, the aim of the present study was to investigate the chemical composition of L. camara essential oil from leaves and stems in different periods. Furthermore, we also analyzed its biological properties by evaluation of antifungal activity and cytotoxic effects against larvae of Artemia salina (brine shrimp assay) and mammalian V79 cells (MTT).

\section{Materials and Methods}

\section{Plant material}

Leaves and stems of Lantana camara L., Verbenaceae, were collected in September of 2008 and June of 2009 in Simões, Piaui, Brazil. The voucher specimen was identified by Professor Jorge Yoshio Tamashiro (IQ-Unicamp), and deposited in the Herbarium Graziela Barroso of Federal University of Piaui, Brazil, under the registration number 27183.

\section{Volatile constituent}

Samples of fresh leaves and stems (about 300 g) of L. camara were subjected to hydrodistillation for $3 \mathrm{~h}$ in a Clevenger-type apparatus from which a yield of about $0.31 \%$ (leaves) and $0.17 \%$ (stems) of oil was obtained. The solvent used was peroxide free diethyl ether. The isolated essential oils were dried over anhydrous sodium sulfate and, after filtration, maintained under refrigeration before analysis.
Gas chromatography-mass spectrometry (CG-MS) and Gas chromatography (FID)

Gas chromatography (GC) analyses were performed on a Hewlett-Packard 5890 SERIES II equipped with a flame ionization detector (FID), column J \& W Scientific DB-5 fused silica (30 m x 0.25 $\mathrm{mm}$ i.d. x $0.10 \mathrm{~mm}$ film thickness). Hydrogen was used as carrier gas at a flow rate of $1.0 \mathrm{~mL} / \mathrm{min}$; split mode (1:10). The injector and detector (FID) temperatures were maintained at $270{ }^{\circ} \mathrm{C}$ and $290{ }^{\circ} \mathrm{C}$, respectively. The column temperature was maintained at $50^{\circ} \mathrm{C}$ for 5 min and then programmed to $180^{\circ} \mathrm{C}$ at a rate of $4{ }^{\circ} \mathrm{C} /$ min, and finally increased to $260^{\circ} \mathrm{C}$ at rate of $10^{\circ} \mathrm{C} / \mathrm{min}$ for $10 \mathrm{~min}$. Samples of $1 \mu \mathrm{L}$ of essential oil diluted in $5 \%$ dichloromethane were injected and $n$-alkanes were used as reference points in the calculation of relative retention indexes. The percentage compositions were obtained from electronic integration measurements of peak area. The mass spectra were recorded on a Shimadzu GC-17A/MS QP5050A-GC-MS system (EI mode $70 \mathrm{eV}$, source temperature $270{ }^{\circ} \mathrm{C}$, scanned mass ranged 43-350 amu). The operating conditions were as described above. The identity of each compound was determined by comparison of its retention index relative to $\mathrm{C}_{8}-\mathrm{C}_{20} n$-alkanes (Fluka Analytical, $1.0 \mathrm{~mL}$ Alkane Standard Solution), as well as of its spectra with the database library Wiley 229. The retention data (retention indexes) were compared to those of the literature (De Lima et al., 2009; Adams, 2007; Joulain \& König, 1998).

\section{Brine shrimp bioassay}

The brine shrimp (Artemia salina Leach) lethality bioassay was carried out to investigate the toxicity of the essential oils of the leaves and stems. Brine shrimp eggs (Maramar) were hatched in artificial salt water $(1.0 \mathrm{~L}$ of mineral water and $33 \mathrm{~g}$ of marine crude $\mathrm{NaCl}$ ) and used after $24 \mathrm{~h}$ applying the modified literature method (Brasil et al., 2009; Parra et al., 2001). Experiments were conducted along with positive control and negative control and different concentrations $(0.02$; $0.04 ; 0.06 ; 0.12 ; 0.23 ; 0.25 ; 0.47 ; 0.50 ; 1.0 ; 5.0 ; 10.0$; $25.0 ; 50.0$ and $100 \mu \mathrm{g} / \mathrm{mL}$ to oil) in a set of three tubes per dose. The percentage lethality was determined by comparing the mean surviving larvae of the test and control tubes. Lethal concentration (LC50) values were obtained from the best-fit line plotting concentration versus percent lethality (Brasil et al., 2009; Meyer et al., 1982). The $50 \%$ lethal concentration (LC50) values of essential oil were determined by Probit analysis (SPSS 15.0). 


\section{V79 cell cytotoxic assay}

Chinese hamster lung fibroblast cells (V79 cells) were cultured under standard conditions in DMEM (Dulbecco's modified Eagle's medium) supplemented with $10 \%$ heat-inactivated FBS (fetal bovine serum), $0.2 \mathrm{mg} / \mathrm{mL}$ L-glutamine, $100 \mathrm{IU} / \mathrm{mL}$ penicillin, and 100 $\mu \mathrm{g} / \mathrm{mL}$ streptomycin. Cells were kept in tissue-culture flasks at $37^{\circ} \mathrm{C}$ in a humidified atmosphere containing $5 \%$ $\mathrm{CO}_{2}$ in air and were harvested by treatment with $0.15 \%$ trypsin- $0.08 \%$ EDTA (ethylene diamine tetraacetic) in PBS (phosphate buffer solution). Cells ( $2 \times 105$ cells) were seeded in complete media and grown for one day prior to treatment with substances and before evaluation with MTT (3-[4,5-dimethylthiazol-2-yl]-2,5-diphenyl tetrazolium bromide) assay. The essential oils, dissolved in DMSO (dimethylsulfoxide), were added to FBS-free media to achieve the different designed concentrations $(10,25,50$ and $100 \mu \mathrm{g} / \mathrm{mL})$, and the cells were treated for $3 \mathrm{~h}$ under standard conditions. The final DMSO concentration in the average never exceeded $0.2 \%$, and the negative control was exposed to an equivalent concentration of solvent. 4-Nitroquinoline-N-oxide (4-NQO- $0.2 \mu \mathrm{g} / \mathrm{mL}$ ) was used as positive control. MTT reduction was performed according to Denizot \& Lang (1986). Briefly after treatments, cells were washed once with PBS before the addition of $0.1 \mathrm{~mL}$ serumfree average containing yellow tetrazolium salt (MTT; $1 \mathrm{mg} / \mathrm{mL}$ ) dye and incubated for $4 \mathrm{~h}$ at $37^{\circ} \mathrm{C}$. After incubation, the supernatant was removed and the purple formazan product was solubilized in $0.2 \mathrm{~mL}$ DMSO, stirred for $15 \mathrm{~min}$, and its absorbance was measured at $570 \mathrm{~nm}$. The absorbance of negative control (DMSO) cells was set as $100 \%$ viability and the values of treated cells were calculated as percentage of negative control (Péres et al., 2009).

\section{Antifungal activity}

The antifungal activity of the essential oil was investigated employing Disc Diffusion Method, according to CLSI (Clinical and Laboratory Standards) M44-A2 (2009). Candida krusei ATCC 6258, granted graciously by the Adolfo Lutz Institute of São Paulo and a sample of Candida albicans isolated from patients with onychomycosis from Teresina, Piauí. About $100 \mathrm{mg}$ of the essential oil was dissolved in distilled water and acetone $(20 \%)$ to a concentration of $100 \mathrm{mg} / \mathrm{mL}, 50 \mathrm{mg} / \mathrm{mL}, 25 \mathrm{mg} / \mathrm{mL}$ and $12.5 \mathrm{mg} / \mathrm{mL}$. The antifungal activity was evaluated by measuring zones of inhibition of fungal growth surrounding the oil. The complete antifungal analysis was carried out under strict aseptic conditions. The zones of inhibition were measured with antibiotic zone scale (CeconBrasil) in $\mathrm{mm}$ and the experiment was carried out in triplicates. The antifungal antibiotics (fluconazole, 25 $\mu \mathrm{g}$; itraconazole, $10 \mu \mathrm{g}$; anfotericine B and terbinafine, $2 \mu \mathrm{g}$-Cecon-Brasil) and water/acetone $20 \%$ were used as positive and negative controls, respectively.

\section{Results and Discussion}

The identification of the essential oils' components was accomplished by comparison of their GC-MS retention indexes. Spectra were considered coincident if the similarity index was higher than $95 \%$. To minimize the standard deviation arising from employing a sole substance as internal standard, we decided to employ a retention index, namely Kovat's Index obtained by the use of a mixture of the essential oil with eight $n$-alkanes as internal standards and using the equation of Van Den Dool \& Dee Kratz (1963) and Kovat's Index experimental $\left(\mathrm{KI}_{\text {exp }}\right)$. This approach greatly improved the identification, especially for those compounds with very similar fragmentation patterns. We also used Kovat's indexes estimated by a computer program based on the least square linear regression that uses the retention times of a few known compounds in the chromatogram and compatibles Kovat's indexes from the literature (Alencar et al., 1990). The estimated Kovat's Index was done on the least square linear regression using six values of KI closer to values in the literature, two at each end and two intermediate, resulting in the following equation: $\mathrm{KI}=690.46404+0.0305 * \mathrm{Rt}$, where $\mathrm{Rt}$ represents the retention time of the sample constituent $(\mathrm{R}=0.99912$; $\mathrm{SD}=14.2$ ), (Figure 1).

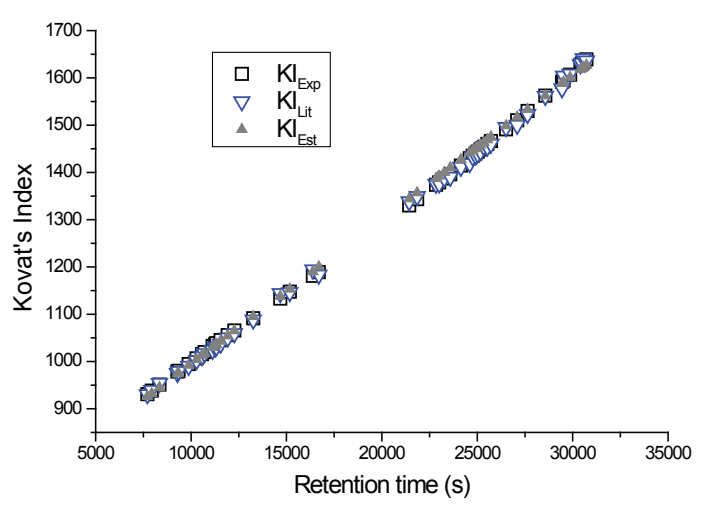

Figure 1. Comparison between values of Kovat's Index: KIexp (computed according to Van Den Dool \& Dee Kratz (1963); KIest and KIlit*. KIa=Spectra were considered coincident if the similarity index was higher than $95 \%$. We also used Kovat's indexes estimated by a computer program (Origin 5.0) based on the least square linear regression that uses the retention times of a few known compounds in the chromatogram and compatibles Kovat's indexes from literature Alencar et al. (1990). $\mathrm{KI}_{\exp }=$ experimental Kovat's index (Van Den Dool \& Dee Kratz (1963)). 
The yields of essential oils obtained by hydrodistillation of the leaves and stems were $0.35 \%$ in June and $0.28 \%$ in September (w/w) and $0.21 \%$ in June and $0.13 \%$ in September $(\mathrm{w} / \mathrm{w})$, respectively. Table 1 gives the chemical composition and retention indexes of the compounds identified. In total 64 compounds were identified: accounting for $98.55 \%$ (in September of 2009) and 95.65\% (in June of 2009) of leaves' oils; $98.78 \%$ (in June of 2009) and 99\% (in September of 2008) of the stems' oil constituents, respectively. The most representative compounds of the oil were mono and sesquiterpenes. The oil from stems of Lantana camara L., Verbenaceae, was characterized by a large amount of sesquiterpenoids, with spatulenol (15.9\%) and caryophyllene oxide (17.1\% in June of 2009), as main components. $\beta$-Gurjunene $(32.7 \%$, in September of 2008) was the most prominent compound in the stems' oils, which was absent or at very low relative abundance in leaves. Unfortunately, there is no other study on stems' oil in the literature for comparison purposes. The main compounds found in the oil of the leaves in different months were $\beta$-caryophyllene (10.5\%, in June of 2009), sabinene (7.98\%, in September of 2008), limonene (7.68\%, in September of 2008), spathulenol (11.64\%, in September of 2008).

The results found show that there were significant differences between the essential oils yields obtained from different collection times (Sousa et al., 2009) as well as significant differences between the chemical composition in the leaves and stems. It can be observed that to obtain the highest essential oils yield, the collection must be carried out during the rainy season (when the yields are more significant).

In particular, the essential oil from leaves of L. camara showed a predominance of sesquiterpenes, similar to species found in other regions (Sousa et al., 2010; Costa et al., 2009; Silva et al., 1999; Randrianalijaona et al., 2005).

Statistical analysis demonstrated that oils showed qualitative and quantitative significant differences when a comparison is made across from the different months (Table 1). When comparing the results of our analyses with those in the literature we identify that our sample represents one new chemotype of $L$. camara. The very different compositions for $L$. camara are consistent with the wide diversity of chemical compositions observed in previous reports for these species (Da Silva et al., 1999).

Our findings indicate that the major compound of $L$. camara essential oils from leaves and stems are sesquiterpenes. We observed that the variability of the composition of essential oil content depends on season, climate and part of the plant studied. It should be noted that many sesquiterpenes identified in the essential oil extracted from leaves also occurred in the oil extracted from stems, independently of collection time. With concentration above $10 \%$, the predominant compounds in the analysis described in the literature were: germacrene $\mathrm{D}$, limonene, $\delta$-curcumene, curcumene, davanone and 1,8-cineole (Ngassoum et al., 1999; Silva et al., 1999; Misra \& Laatsch, 2000; Alitonou et al., 2004; Hernández et al., 2005; Sonibare \& Effiong, 2008).

Table 1. Chemical composition of the essential oil, obtained by hydrodistillation, from leaves and stems of L. camara.

\begin{tabular}{|c|c|c|c|c|c|}
\hline \multirow{3}{*}{ Components $^{\mathrm{a}}$} & \multirow{3}{*}{ K.I. ${ }^{b}$} & \multicolumn{4}{|c|}{ Area $(\%)$} \\
\hline & & \multicolumn{2}{|c|}{ Leaves } & \multicolumn{2}{|c|}{ Stems } \\
\hline & & June/2009 & September/2008 & June/2009 & September $/ 2008$ \\
\hline$\alpha$-thujene & 931 & 0.99 & ---- & ---- & ---- \\
\hline$\alpha$-pinene & 938 & 3.06 & ---- & ---- & ---- \\
\hline camphene & 951 & 0.31 & 1.47 & ---- & ---- \\
\hline$\beta$-pinene & 974 & --- & 3.68 & --- & --- \\
\hline sabinene & 979 & 4.44 & 7.98 & 1.51 & 1.16 \\
\hline$\gamma$-pinene & 980 & 0.25 & ---- & ---- & ---- \\
\hline myrcene & 995 & 1.08 & 2.01 & ---- & ---- \\
\hline$\alpha$-phellandrene & 1007 & 0.76 & 3.17 & --- & --- \\
\hline$\delta$-3-carene & 1016 & 5.01 & 4.32 & ---- & 2.48 \\
\hline$\alpha$-terpinene & 1019 & 0.31 & 1.02 & ---- & - \\
\hline limonene & 1024 & ---- & 7.68 & 1.51 & 2.22 \\
\hline$\beta$-ocimene & 1032 & ---- & 2.38 & ---- & ---- \\
\hline p-cymene & 1033 & 4.43 & 5.07 & 5.41 & ---- \\
\hline$\beta$-phellandrene & 1037 & 4.82 & & ---- & ---- \\
\hline
\end{tabular}


Table 1. Chemical composition of the essential oil, obtained by hydrodistillation, from leaves and stems of L. camara. (cont.)

\begin{tabular}{|c|c|c|c|c|c|}
\hline 1,8-cineole & 1039 & 1.00 & 2.67 & 1.31 & 1.47 \\
\hline cis- $\beta$-ocimene & 1045 & 1.45 & ---- & ---- & ---- \\
\hline trans- $\beta$-ocimene & 1056 & 2.20 & ---- & ---- & ---- \\
\hline$\gamma$-terpinene & 1066 & 2.02 & 3.43 & ---- & ---- \\
\hline$\alpha$-terpinolene & 1091 & 0.87 & 1.36 & ---- & ---- \\
\hline linalool & 1095 & ---- & 1.26 & ---- & ---- \\
\hline neo-allo-ocimene & 1133 & 0.22 & ---- & ---- & ---- \\
\hline camphor & 1148 & 0.08 & 0.75 & ---- & ---- \\
\hline terpinene-4-ol & 1174 & ---- & 1.78 & 3.40 & 0.51 \\
\hline neo-dihydro carveol & 1181 & 0.53 & ---- & ---- & ---- \\
\hline crytone & 1189 & 0.14 & ---- & ---- & ---- \\
\hline$\delta$-elemene & 1330 & 0.28 & ---- & ---- & ---- \\
\hline bicicloelemene & 1338 & ---- & ---- & 2.56 & ---- \\
\hline linalool propanoate & 1339 & ---- & ---- & 1.69 & ---- \\
\hline$\alpha$-terpinyl acetate & 1344 & 3.65 & ---- & ---- & ---- \\
\hline$\alpha$-ylangene & 1374 & 0.20 & ---- & ---- & ---- \\
\hline$\alpha$-copaene & 1379 & 0.79 & ---- & ---- & ---- \\
\hline$\beta$-bourbonene & 1387 & 0.44 & ---- & 3.63 & ---- \\
\hline$\beta$-elemene & 1396 & 2.05 & ---- & 5.00 & --- \\
\hline italicene & 1404 & ---- & ---- & ---- & 1.05 \\
\hline$\alpha$-cendrene & 1414 & 0.53 & ---- & ---- & ---- \\
\hline iso-caryophyllene & 1417 & ---- & 10.38 & ---- & ---- \\
\hline$\alpha$-cis-bergamotene & 1423 & ---- & ---- & ---- & 1.35 \\
\hline$\beta$-caryophyllene & 1430 & 10.55 & ---- & 13.13 & 32.69 \\
\hline$\beta$-gurjunene & 1435 & 0.56 & ---- & 0.47 & ---- \\
\hline$\gamma$-elemene & 1440 & 1.50 & ---- & 0.47 & ---- \\
\hline$\alpha$-guaiene & 1444 & 0.37 & ---- & ---- & ---- \\
\hline guaiadiene $<6,9>$ & 1448 & 0.27 & ---- & ---- & --- \\
\hline khusimene & 1454 & 0.30 & ---- & ---- & ---- \\
\hline$\alpha$-humulene & 1460 & 1.99 & 1.45 & 2.23 & 3.30 \\
\hline allo-aromadendrene & 1466 & 1.17 & ---- & 0.97 & 0.97 \\
\hline germacrene-D & 1448 & ---- & 4.60 & 4.30 & 8.49 \\
\hline$\beta$-silinene & 1487 & ---- & ---- & 1.05 & --- \\
\hline$\gamma$-amorphene & 1491 & 8.29 & ---- & ---- & --- \\
\hline bicyclogermacrene & 1510 & 10.62 & 11.69 & 12.96 & 13.93 \\
\hline$\delta$-cadinene & 1530 & 0.93 & ---- & 1.77 & 2.37 \\
\hline 1,4-cadinadiene & 1530 & ---- & ---- & 0.56 & 0.61 \\
\hline selina-3,5(11)-diene & 1541 & ---- & ---- & 1.81 & ---- \\
\hline Junipene & 1555 & ---- & ---- & 1.94 & ---- \\
\hline$\gamma$-gurjunene & 1458 & --- & --- & 1.06 & 0.51 \\
\hline germacrene B & 1562 & 2.73 & 0.97 & ----- & 1.88 \\
\hline caryophyllene oxide & 1581 & --- & 5.57 & 17.10 & 6.63 \\
\hline spathulenol & 1591 & 7.04 & 11.64 & ---- & 15.90 \\
\hline$\beta$-selinene & 1592 & ---- & 1.16 & ---- & ---- \\
\hline khusimone & 1594 & 1.23 & ---- & ---- & ---- \\
\hline
\end{tabular}


Table 1. Chemical composition of the essential oil, obtained by hydrodistillation, from leaves and stems of L. camara. (cont.)

\begin{tabular}{|c|c|c|c|c|c|}
\hline$\beta$-atlantol & 1606 & 0.33 & ---- & ---- & ---- \\
\hline$\beta$-guaiene & 1614 & ---- & ---- & ---- & 2.67 \\
\hline $\mathrm{Ni}$ & 1623 & ---- & 1.31 & ---- & ---- \\
\hline 1-epi-cubenol & 1627 & 4.67 & 1.55 & ---- & ---- \\
\hline eemoligenol & 1630 & 0.27 & ---- & ---- & ---- \\
\hline allo-aromadendrene epoxide & 1633 & 0.24 & ---- & 0.91 & ---- \\
\hline$\beta$-acorenol & 1639 & 0.68 & ---- & ---- & ---- \\
\hline $\mathrm{Ni}$ & 1652 & 1.62 & ---- & ---- & ---- \\
\hline$\gamma$-cadinene & 1665 & ---- & ---- & 7.90 & ---- \\
\hline $\mathrm{Ni}$ & 1665 & 2.70 & ---- & ---- & ---- \\
\hline $\mathrm{Ni}$ & 2120 & ---- & ---- & 3.59 & 0.21 \\
\hline neophytadiene & 2223 & ---- & ---- & 0.59 & ---- \\
\hline Total (\%) & & 99.97 & 99.86 & 98.78 & 99.21 \\
\hline
\end{tabular}

${ }^{\mathrm{a}}$ Compounds listed in order to their elution on the DB-5HT column. ${ }^{\text {b}}$ Retention indexes on the DB-5HT column relative to C8-C ${ }_{20} n$-alkanes. --undetected. Ni: not identified.

The brine shrimp (Artemia salina) assay is a convenient preliminary toxicity test because brine shrimp is highly sensitive to a variety of chemical substances. Meyer et al., (1982) established a relationship between the level of toxicity and lethal concentration by extract of plants on larvae of $A$. salina, being toxic when those values are below $1000 \mathrm{mg} / \mathrm{mL}$. Thus, we observed a high toxicity level of essential oils from leaves and stems of $L$. camara against $A$. salina with a lethal concentration LC50 $0.234 \mu \mathrm{g} / \mathrm{mL}$, with limits between 0.195 and $0.273 \mu \mathrm{g} / \mathrm{mL}$ (Figure 2) when compared to values for the controls beberine chloride (LC50 of 22.5 $\mu \mathrm{g} / \mathrm{mL}$ ) and strychnine sulfate (LC50 of $77.2 \mu \mathrm{g} / \mathrm{mL}$ ) obtained by Meyer et al. (1982), confirming the earlier work which showed that Lantana spp. is highly toxic (Costa et al., 2009; Sonibare \& Effiong, 2008).

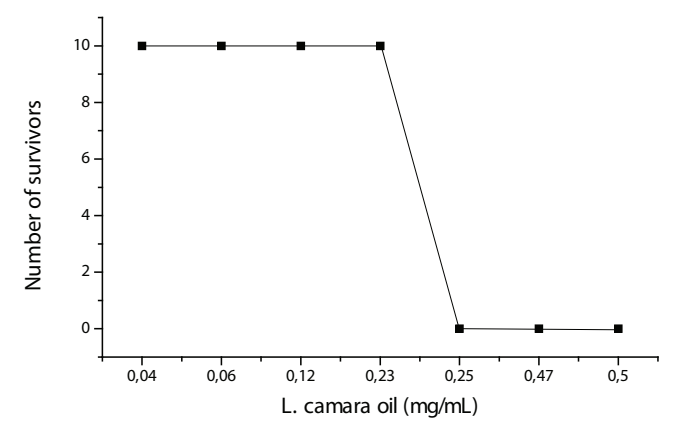

Figure 2. Cytotoxicity test with $A$. salina made with essential oil of L. camara in the range of concentrations between 0.02 a $0.5 \mathrm{mg} / \mathrm{mL}$.
The cytotoxic effects of $L$. camara was evaluated in V79 mammalian cells. As can be seen in Figure 3, essential oil from L. camara leaves induces a significant decrease in cells survival at concentrations of $25 \mu \mathrm{g} / \mathrm{mL}$ and higher. The chemical composition analysis pointed as major compounds of the $L$. camara leaves essential oil the sesquiterpenes, bicyclogermacrene, $(+)$ spathulenol, transcaryophyllene and sabinene (Table 1). Generally, these major compounds determine the biological properties of the essential oils (Bakkali et al., 2008), nevertheless this effect can be influenced by the chemical composition and the synergism between the various components (Wright et al., 2007). Wright et al., (2007), working with essential oils from leaves of Beilschmiedia sp. nov., Cinnamomum costaricanum, Ocotea Meziane and Ocotea sp. nov. spatted that there was synergism between the major components and those minor one . Loizzo et al. (2008) evaluated various constituents of essential oils and found that $\alpha$-pinene was inactive alone but had synergistic effect with other components of essential oil of Cupressus sempervirens spp. The cytotoxic effects of essential oil of $L$. camara can be related to the presence of terpenes (Bakkali et al., 2008).The terpenes as typical lipophiles can pass through the cytoplasmic membranes, disrupt the different layer of polysaccharides, fatty acids and phospholipids and permeabilize them, and the membrane damage can be related to essential oil cytotoxic effects (Bakkali et al., 2008). Moreover, the cytotoxic effects of these sesquiterpenes have been previously associated to normal and tumoral cells. Bicyclogermacrene has cytotoxic activity against HepG2 (hepatocellular liver carcinoma), MCF-7 (breast cancer), and PC-3 (prostate cancer) tumor cell lines, while spathulenol are toxic to both normal lung cells (MRC5) and gastric adenocarcinoma cells (AGS) (Boehme et al., 2008; Areche et al., 2009; Ashour et al., 
2009; Tundis et al., 2009). Effects of caryophyllene are controversial. Some studies indicate that caryophyllene, common in this species, does not exhibit any cytotoxic activity against human cells Prashar et al., (2006) and Legault et al., (2003), but other studies showed that $\beta$-caryophyllene is active against breast carcinoma cells lines BT-20 ATCC HTB 19, Kubo \& Morimitsu (1995). According to Bakkali et al. (2008): $\alpha$-terpinene, sabinene, limonene, cymene, $\beta$-caryophyllene have cytotoxic activities, dose dependent, when tested alone or added to the essential oil. But, the exact mechanism of these compounds is not known yet.

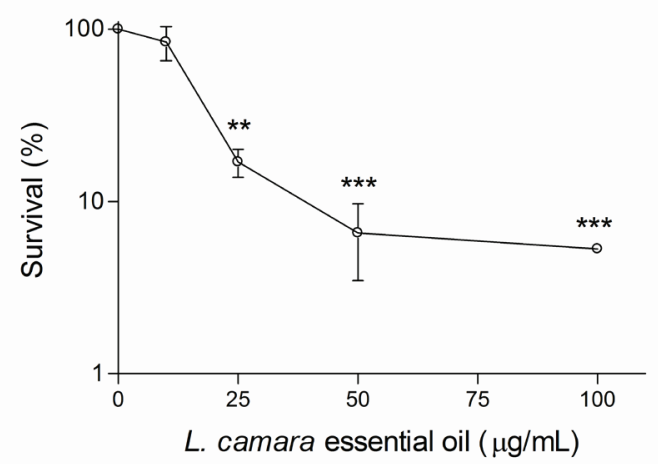

Figure 3. Cytotoxic effects of L. camara essential oil in V79 mammalian cells after $3 \mathrm{~h}$ exposure analyzed by MTT assay. Results are expressed as mean percentage in treated cells compared to control (solvent) \pm standard deviation of three independent experiments. Data significant in relation to control (solvent) at $* * p<0.01$ and $* * * p<0.001 /$ one-way ANOVA-Dunet's multiple comparison test.

The relative efficacy of some commonly used antifungal antibiotics was compared with essential oil discs by employing the Filter paper Disc Diffusion Method. Table 2 summarizes the in vitro susceptibilities to the four antifungal agents (some of them used currently to treat candidiasis, Paiva et al., 2009) and for essential oil of L. camara. Resistance to fluconazole and terbinafine were mostly noted in C. krusei, but it was not observed in C. albicans, the most common pathogen among cutaneous candidiasis and of the oropharynx. Candida krusei is known to have intrinsic resistance, particularly to fluconazole and to azolic derivatives in general (Crocco et al., 2004; Rex et al., 2000). Cases of Candida albicans resistance to azolic derivatives in HIV-infected (human immunodeficiency virus) patients and in patients with invasive candidiasis were reported (Crocco et al., 2004). This essential oil remarkably inhibited the growth of the fungi tested: C. krusei ATCC 6258, and C. albicans isolated from patient with onychomycosis. However, its higher efficiency should be tested in larger concentration and also carefully check their toxicity.

\section{Conclusions}

In summary, when compared to literature data, our study evidenced some differences in the chromatographic profile as well as in quantitative composition of essential oil Lantana camara L., Verbenaceae. The cytotoxicity assay with $A$. salina was consistent with those obtained for V79 cells mammalian, and this oil remarkably inhibited the growth of tested fungi. Therefore, our data corroborate the toxicity of the essential oil of L. camara, as indicated in many references cited in this work; and because of its high toxicity all internal uses for humans must be excluded or done with great caution.

\section{Acknowledgment}

The authors are grateful to UFPI and CAPES for their financial support and research fellowships and to Lapetro-UFPI for analysis, and to Professor Jorge Yoshio Tamashiro (IQ-Unicamp) for botanical identification, as well as to Prof. Carlos Lairon Morais for grammatical revision.

\section{References}

Adams RP 2007. Identification of essential oil components by gas chromatography/mass spectrometry. Carol Stream: Allured Publishing Corporation.

Alencar JW, Craveiro AA, Matos FJA, Machado MIL 1990. Kovats indices simulation in essential oils analysis. Quim Nova 13: 282-284.

Alitonou G, Avlessi F, Bokossa I, Ahoussi E, Dangou J, Sohounhloué DCK 2004. Composition chimique et activités biologiques de 1'huile essentielle de Lantana camara Linn. CR Chim 7: 1101-1105.

Areche C, Schmeda-Hirschmann G, Theoduloz C, Rodríguez JA 2009. Gastroprotective effect and cytotoxicity

Table 2. Antifungal activity of essential oil from leaves of L. camara in comparison with some antifungal antibiotics.

\begin{tabular}{|c|c|c|c|c|c|c|c|c|}
\hline \multicolumn{5}{|c|}{$\begin{array}{l}\text { Essential oil inhibition (oil concentration } 100 \mathrm{mg} / \mathrm{mL} \text {, } \\
50,25 \text { and } 12.5 \mathrm{mg} / \mathrm{mL} \text { ) }\end{array}$} & Anfotericine & Fluconazole & Itraconazole & Terbinafine \\
\hline Strains & \multicolumn{4}{|c|}{ Zone of inhibition in $\mathrm{mm}$} & \multicolumn{4}{|c|}{ Zone of inhibition in $\mathrm{mm}$} \\
\hline C. krusei & 14 & 12 & 12 & 10 & 29 & resistance & 21 & resistance \\
\hline C. albicans & 13 & 11 & 11 & 11 & 19 & 29 & 19 & resistance \\
\hline
\end{tabular}


of abietane diterpenes from the Chilean Lamiaceae Sphacele chamaedryoides (Balbis) Briq. J Pharm Pharmacol 61: 1689-1697.

Ashour ML, El-Readi M, Youns M, Mulyaningsih S, Sporer F, Efferth T, Wink M 2009. Chemical composition and biological activity of the essential oil obtained from Bupleurum marginatum (Apiaceae). J Pharm Pharmacol 61: 1079-1087.

Bakkali F, Averbeck S, Averbeck D, Idaomar M 2008. Biological effects of essential oils-a review. Food Chem Toxicol 46: 446-475.

Bastianetto E, Cunha AP, Bello ACPP, Melo MM 2005. Intoxicação de bezerros búfalos por Lantana spp. em Minas Gerais: relato de casos. Rev Bras Reprod Anim 29: 57-59.

Begum S, Ua SYM, Siddiqui BIH, Diqui S 1995. Triterpenoids from the aerial parts of Lantana camara. J Nat Prod 58: 1570-1574.

Begum S, Wahab A, Siddiqui BS, Qamar F 2000. Nematicidal constituents of the aerial parts of Lantana camara. $J$ Nat Prod 63: 765-767

BoehmeAK, Noletto JA, HaberWA, SetzerWN2008. Bioactivity and chemical composition of the leaf essential oils of Zanthoxylum rhoifolium and Zanthoxylum setulosum from Monteverde, Costa Rica. Nat Prod Res 22: 31-36.

Brasil DSB, Muller AH, Guilhon GMSP, Alves CN, Andrade EHA, Da Silva JKR, Maia JGS 2009. Essential oil composition of Croton palanostigma Klotzsch from north Brazil. J Braz Chem Soc 20: 1188-1192.

Clinical and Laboratory Standards Institute (CLSI). 2009. Method for antifungal disk diffusion susceptibility testing of yeasts. 2th ed. CLSI document M44-A2. Pennsykvania, USA.

Costa JGM, Rodrigues FFG, Sousa EO, Junior DMS, Campos AR, Coutinho HDM, De Lima SG 2010. Composition and lavicidal activity of the essential oils of Lantana camara and Lantana montevidensis. Chem Nat Compd 46: 313-315.

Costa JGM, Sousa EO, Rodrigues FFG, Lima SGD, Braz-Filho R 2009. Composição química e avaliação das atividades antibacteriana e de toxicidade dos óleos essenciais de Lantana camara L. e Lantana sp. Rev Bras Farmacogn 19: 710-714.

Crocco EI, Mimica LMJ, Muramatu LH, Garcia C, Souza VM, Ruiz LRB, Zaitz C 2004. Identification of Candida species and antifungal susceptibility in vitro: a study on 100 patients with superficial candidiasis. An Bras Dermatol 79: 689-697.

Da Silva MHL, Andrade EHA, Zoghbi MGB, Luz AIR, Da Silva JD, Maia JGS 1999. The essential oils of Lantana camara L. occurring in North Brazil. Flavour Frag $J$ 14: 208-210.

De Lima SG, Moita Neto JM, Costa JGMD, Citó AMGL, Reis FAM 2009. Monoterpenes, sesquiterpenes and fatty acids from Julocroton triqueter (euphorbiaceae) from
Ceará-Brazil. J Chil Chem Soc 53: 1718-1720.

Denizot F, Lang R 1986. Rapid colorimetric assay for cell growth and survival: Modifications to the tetrazolium dye procedure giving improved sensitivity and reliability. $J$ Immunol Methods 89: 271-277.

Ghisalberti EL 2000. Lantana camara L. (Verbenaceae) Review. Fitoterapia 71: 467-486.

Hayashi K, Chang F, Nakanishi Y, Bastow KF, Cragg G, Mcphail AT, Hi Nozaki H, Lee K 2004. Antitumor agents. 233.1 lantalucratins A-F, new cytotoxic naphthoquinones from Lantana involucrate. J Nat Prod 67: 990-993.

Herbert JM, Maffrand JP, Taoubi K, Augereau JM, Fouraste I, Gleye J 1991. Verbascoside isolated from Lantana camara, an inhibitor of protein kinase C. J Nat Prod 54: 1595-1600.

Hernández T, Canales M, Avila JG, García AM, Martínez A, Caballero J, Romo De Vivar A, Lira R 2005. Composition and antibacterial activity of essential oil of Lantana achyranthifolia Desf. (Verbenaceae). J Ethnopharmacol 96: 551-554.

Jiménez-Arellanes A, Meckes M, Torres J, Luna-Herrera J 2007. Antimycobacterial triterpenoids from Lantana hispida (Verbenaceae). J Ethnopharmacol 111: 202-205.

Joulain D, König WA 1998. The atlas of spectral data of sesquiterpene hydrocarbons. Hamburg: E.B.-Verlag.

Julião LDS, Piccinelli AL, Marzocco S, Leitão SG, Lotti C, Autore G, Rastrelli L 2009. Phenylethanoid glycosides from Lantana fucata with in vitro anti-inflammatory activity. J Nat Prod 72: 1424-1428.

Kubo I, Morimitsu Y 1995. Cytotoxicity of green tea flavor compounds against two solid tumor cells. J Agric Food Chem 43: 1626-1628.

Legault J, Dahl W, Debiton E, Pichette A, Madelmont JC 2003. Antitumor activity of balsam fir oil: production of reactive oxygen species induced by $\alpha$-humulene as possible mechanism of action. Planta Med 69: 402407.

Litaudon M, Jolly C, Callonec CL, Cuong DD, Retailleau P, Nosjean O, Nguyen VH, Pfeiffer B, Boutin JA, Guéritte F 2009. Cytotoxic pentacyclic triterpenoids from Combretum sundaicum and Lantana camara as inhibitors of $\mathrm{Bcl}-\mathrm{xL} / \mathrm{BakBH} 3$ domain peptide interaction. J Nat Prod 72: 1314-1320.

Loizzo MR, Tundis R, Menichini F, Saab AM, Statti GA, Menichini F 2008. Antiproliferative effects of essential oils and their major constituents in human renal adenocarcinoma and amelanotic melanoma cells. Cell Proliferat 41: 1002-1012.

Lorenzi H, Matos FJA 2002. Plantas medicinais no Brasil: nativas e exóticas cultivadas. Nova Odessa: Instituto Plantarum.

Mello FB, Kelly DJ, João C, Mello RB 2005. Effects of Lantana camara (Verbenaceae) on general reproductive performance and teratology in rats. Toxicon 45: 459466. 
Meyer BN, Ferrigni NR, Putnam JE, Jacobsen LB, Nichols DE, Mclaughlin JL 1982. Brine shrimp: a convenient general bioassay for active plant constituents. Planta Med 45: 31-34.

Misra L, Laatsch H 2000. Triterpenoids, essential oil and photo-oxidative 2813-lactonization of oleanolic acid from Lantana camara. Phytochemistry 54: 969-974.

Ngassoum MB, Yonkeu S, Jirovetz L, Buchbauer G, Schmaus G, Hammerschmidt F-J 1999. Chemical composition of essential oils of Lantana camara leaves and flowers from Cameroon and Madagascar. Flavour Frag J 14: 245-250.

O’Neill MJ, Lewis JA, Noble HM, Holland S, Mansat C, Farthing JE, Foster G, Noble D, Lane SJ, Sidebottom PJ, Lynn SM, Hayes MV, Dix CJ 1998. Isolation of translactone-containing triterpenes with thrombin inhibitory activities from the leaves of Lantana camara. J Nat Prod 61: 1328-1331.

Paiva ICA, Ribeiro RA, Pereira JV, Oliveira NMC 2009. Clinical and laboratorial evaluation of Uncaria tomentosa (Cat's Claw) gel on oral candidiasis. Rev Bras Farmacogn 19: 423-428.

Parra AL, Yhebra RS, Sardiñas G, Jacobsen LB, Buela LI 2001. Comparative study of the assay of Artemia salina $\mathrm{L}$. and the estimate of the medium lethal dose (LD50 value) in mice, to determine oral acute toxity of plant extract. Phytomedicine 8: 395-400.

Pereira AC, Carvalho HWP, Silva GH, Oliveira DF, Figueiredo HCP, Cavalheiro AJ, Carvalho DA 2008. Purification of an antibacterial compound from Lantana lilacina. Rev Bras Farmacogn 18: 204-208.

Prashar A, Locke IC, Evans CS 2006. Cytotoxicity of clove (Syzygium aromaticum) oil and its major components to human skin cells. Cell Proliferat 39: 241-248.

Péres VF, Moura DJ, Sperotto ARM, Damasceno FC, Caramão EB, Zini CA, Saffi J 2009. Chemical composition and cytotoxic, mutagenic and genotoxic activities of the essential oil from Piper gaudichaudianum Kunth leaves. Food Chem Toxicol 47: 2389-2395.

Randrianalijaona JA, Ramanoelina PAR, Rasoarahona JRE, Gaydou EM 2005. Seasonal and chemotype influences on the chemical composition of Lantana camara L. Essential oils from Madagascar. Anal Chim Acta 545: 46-52.

Rex JH, Walsh TJ, Sobel JD, Filler SG, Pappas PG, Dismukes WE, Edwards JE. Practice guidelines for the treatment of Candidiasis. J Infect Dis 30: 662-678.

Rwangabo PC, Claeys M, Pieters L, Corthout J, Vanden Berghe DA, Vlietinck AJ 1988. Umuhengerin, a new antimicrobially active flavonoid from Lantana trifolia. J Nat Prod 51: 966-968.

Silva MHLD, Andrade EHA, Zoghbi MDGB, Luiz AIR, Silva JDD, Maia JGS 1999. The essential oils of Lantana camara L. occurring in North Brazil. Flavour Frag $J$ 14: 208-210.
Singh SK, Tripathi VJ, Singh RH 1991. A new pentacyclic triterpene acid from Lantana indica. J Nat Prod 54: $755-758$.

Sonibare OO, Effiong I 2008. Antibacterial activity and cytotoxicity of essential oil of Lantana camara L. leaves from Nigeria. Afr J Biotechnol 7: 2618-2620.

Sousa EO, Almeida TS, Menezes IRA, Rodrigues FFG, Campos AR, De Lima SG, Da Costa JGM 2012. Chemical composition of essential oil of Lantana camara L. (Verbenaceae) and synergistic effect of the aminoglycosides gentamicin and amikacin. Rec Nat Prod 6: 144-150.

Sousa EO, Colares AV, Rodrigues FFG, Campos AR, De Lima SG, Costa JGM 2009. Effect of collection time on essential oil composition of Lantana camara Linn (Verbenaceae) growing in Brazil Northeastern. Rec Nat Prod 4: 31-37.

Sousa EO, Rodrigues FFG, Coutinho HDM, Campos AR, De Lima SG, Costa JGM 2011. Chemical composition and aminoglycosides synergistic effect of Lantana montevidensis Briq. (Verbenaceae) essential oil. Rev Fitos 5: 60-64.

Sousa EO, Silva NF, Rodrigues FFG, Campos AR, De Lima SG, Costa JGM 2010. Chemical composition and resistance-modifying effect of the essential oil of Lantana camara Linn. Pharmacogn Mag 22: 78-82.

Tundis R, Loizzo MR, Bonesi M, Menichini F, Dodaro D, Passalacqua NG, Statti G, Menichini F 2009. In vitro cytotoxic effects of Senecio stabianus Lacaita (Asteraceae) on human cancer cell lines. Nat Prod Res 23: 1707-1718.

Van Den Dool H, Dee Kratz P 1963. A generalization of the retention index system including linear temperature programmed gas-liquid partition chromatography. $J$ Chromatogr A 11: 463-471.

Weir MP, Bethell SS, Cleasby A, Campbell CJ, Dennis RJ, Dix CJ, Finch H, Jhoti H, Mooney CJ, Patel S, Tang C, Ward M, Wonacott AJ, Wharton CW 1998. Novel natural product 5,5-trans-lactone inhibitors of human $\alpha$-thrombin: mechanism of action and structural studies. Biochemistry 37: 6645-6657.

Wright BS, Bansal A, Moriarity DM, Takaku S, Setzer WN 2007. Cytotoxic leaf essential oils from Neotropical lauraceae: Synergistic effects of essential oil components. Nat Prod Commun 2: 1241-1244.

\section{*Correspondence}

Sidney Gonçalo de Lima

Departamento de Química, Universidade Federal do Piauí Campus Universitário Petrônio Portela, s/n, 64049-550

Teresina-PI, Brazil

sidney@ufpi.edu.br

Tel.: + $55863215-5840$

Fax: $+55863215-5692$ 